\title{
Efek Gel Ekstrak Kulit Buah Manggis (Garcinia Mangostana) pada Perlekatan Komposit pasca In-Office Bleaching
}

\author{
Farah Amiria*, Harwoko**, dan A. Haris Budi Widodo* \\ *Jurusan Kedokteran Gigi, Universitas Jenderal Soedirman, Purwokerto, Jawa Tengah, Indonesia \\ **Jurusan Farmasi, Universitas Jenderal Soedirman, Purwokerto, Jawa Tengah, Indonesia \\ *Jl. dr. Soeparno Karangwangkal, Purwokerto, Jawa Tengah, Indonesia; e-mail: farah_amiria@yahoo.com
}

\begin{abstract}
ABSTRAK
Hidrogen peroksida pada perawatan in-office bleaching meninggalkan residu yang dapat menghambat polimerisasi pada sistem resin bonding. Asam askorbat $10 \%$ sebagai antioksidan dapat mengeliminasi residu peroksida sebelum proses penumpatan. Kulit buah manggis (Garcinia mangostana) memiliki aktivitas antioksidan yang berpotensi untuk menggantikan peran asam askorbat. Penelitian ini bertujuan untuk membuktikan efek gel ekstrak kulit buah manggis dalam memperbaiki perlekatan komposit pada gigi pasca in-office bleaching. Penelitian ini merupakan penelitian eksperimental laboratorium. Sebanyak 25 gigi premolar pertama rahang atas dilakukan in-office bleaching dan selanjutnya dibagi menjadi 5 kelompok terdiri dari kontrol negatif (tanpa agen antioksidan), kontrol positif (asam askorbat $10 \%$ ), dan kelompok perlakuan gel ekstrak kulit buah manggis $10 \%, 20 \%$, dan $40 \%$. Perlekatan komposit ditentukan dengan uji geser, dilanjutkan pengamatan mikrostruktur permukaan email. Hasil penelitian menunjukkan nilai perlekatan komposit pada kelompok kontrol negatif dan kontrol positif berturut-turut sebesar 25,82 $\pm 2,88 \mathrm{Mpa}$ dan 37,68 $\pm 1,06 \mathrm{Mpa}$. Pada kelompok perlakuan gel ekstrak kulit manggis $10 \%, 20 \%$, dan $40 \%$ diperoleh nilai perlekatan berturut-turut sebesar $26,54 \pm 2,68 ; 32,64 \pm 2,33$; dan $57,34 \pm 1,51 \mathrm{Mpa}$. Nilai perlekatan komposit pada pemberian gel ekstrak kulit manggis $20 \%$ dan $40 \%$ berbeda signifikan dibandingkan dengan kontrol negatif maupun kontrol positif $(p<0,05)$. Kenaikan konsentrasi gel ekstrak kulit manggis memberikan peningkatan jumlah fraktur email. Gel ekstrak kulit manggis $20 \%$ dan $40 \%$ dapat memperbaiki perlekatan komposit sehingga berpotensi sebagai agen antioksidan pada gigi pasca in-office bleaching. Maj Ked Gi Ind. Juni 2015; 1(1): hal 32-37
\end{abstract}

Kata Kunci: Garcinia mangostana, manggis, in-office bleaching, komposit

\begin{abstract}
Effect of Mangosteen Gel on Shear Bond Strength Of Composite Post In-Office Bleaching. The residual peroxide after in-office bleaching inhibits the polymerization of the resin bonding systems. Ascorbic acid (10\%) as anti-oxidant agent has a potential to remove the residual peroxide before restoration procedure. Mangosteen extract has an anti-oxidant potential that can be used to remove the residual peroxide. The aim of the study is to prove the effect of mangosteen extract gel to improve shear bond strength of composite post in-office bleaching. The experimental laboratory design was implemented to this research. The study was carried out on 25 maxillary first premolars that had been applied in-office bleaching procedure. The teeth were divided into five groups as follow: negative-control group (without anti-oxidant agent), positive-control group (10\% ascorbic acid), and the treatment groups (10\%, 20\%, and $40 \%$ mangosteen extract gel). Shear bond strength of the specimens was tested and followed by microstructure testing on email. The results show that negative-control and positive-control group scores were 25,82 2,88 Mpa and $37,68 \pm 1,06 \mathrm{Mpa}$, followed by the scores of $10 \%, 20 \%$, and $40 \%$ mangosteen extract gel groups which were 26,54 2,68 ; $32,64 \pm 2,33$; and 57,34 $\pm 1,51 \mathrm{Mpa}$ respectively. Significant higher shear bond strength values were observed in $20 \%$ and $40 \%$ mangosteen extract gel groups compared to the negative-control and positive-control group $(p<0,05)$. The increasing concentration of mangosteen extract gel provided increasing number of email fractures. Mangosteen extract gel $20 \%$ and $40 \%$ improve the shear bond strength of composite, confirming its potential as an antioxidant agent for the teeth post in-office bleaching.

Maj Ked Gi Ind. Juni 2015; 1(1): hal 32-37
\end{abstract}

Keywords: Garcinia mangostana, mangosteen, in-office bleaching, composite

\section{PENDAHULUAN}

Bleaching merupakan suatu cara pemutihan kembali gigi yang berubah warna sampai mendekati warna gigi asli dengan proses perbaikan secara kimiawi. ${ }^{1}$ Karbamid peroksida $\left(\mathrm{CH}_{6} \mathrm{~N}_{2} \mathrm{O}_{3}\right)$ dan hidrogen peroksida $\left(\mathrm{H}_{2} \mathrm{O}_{2}\right)$ merupakan bahan kimia yang digunakan dalam proses bleaching. Hidrogen peroksida merupakan bahan yang memiliki sifat oksidator kuat dan umumnya digunakan sebagai bahan in-office bleaching pada konsentrasi 30$35 \%$. Hidrogen peroksida mempunyai berat molekul rendah dan mampu menembus ke dalam email. 
Proses mendasar untuk pemutihan gigi adalah reaksi oksidasi. Hidrogen peroksida melepaskan oksigen yang merusak ikatan dalam rantai protein yang bergabung dengan stain dalam ikatan tunggal. ${ }^{2}$

Gigi menjadi lebih putih akibat bebasnya molekul pigmen, namun proses bleaching dapat menimbulkan efek samping, diantaranya mengurangi kemampuan perlekatan bahan tumpat seperti resin komposit. Hidrogen peroksida yang diaplikasikan pada enamel akan meninggalkan sisa peroksida pada permukaan gigi dan selanjutnya akan menghambat polimerisasi sistem resin bonding. ${ }^{3}$ Bahan resin bonding yang terdapat pada enamel yang telah diberikan etsa tidak sepenuhnya terpolimerisasi. Struktur seperti gelembung dapat diamati pada lapisan resin bonding. Hal ini menunjukkan bahwa oksigen yang dilepaskan oleh hidrogen peroksida terperangkap di dalam resin bonding selama proses light cure. Akibatnya terjadi kerusakan retensi mekanis sehingga daya perlekatan resin komposit akan menurun. ${ }^{4}$

Sebelum dilakukan penumpatan dengan resin komposit, residual hidrogen peroksida pada gigi pasca bleaching perlu dieliminasi dengan penundaan prosedur penumpatan selama satu minggu pasca bleaching, menggunakan alkohol, atau aplikasi asam askorbat $10 \%$. Penggunaan asam askorbat 10\% sebagai agen antioksidan telah terbukti tidak toksik dan aman digunakan untuk mengeliminasi residu hidrogen peroksida pada gigi pasca bleaching. ${ }^{5}$ Asam askorbat yang memiliki aktivitas antioksidan merupakan reduktor yang mampu menyumbangkan dua elektron energi tinggi untuk berikatan dengan radikal bebas. ${ }^{4}$ Banyak tanaman yang terbukti sebagai antioksidan alami, diantaranya adalah manggis (Garcinia mangostana L.) yang dimanfaatkan bagian kulit buahnya. ${ }^{6}$

Senyawa utama dalam kulit buah manggis yang telah diteliti memiliki beberapa aktivitas farmakologi adalah golongan xanton. Senyawa golongan ini yang berpotensi sebagai antioksidan adalah 8-hidroksikudraxanton, gartanin, alphamangostin, gamma-mangostin, dan smeathxanton A. ${ }^{6}$ Ekstrak air, ekstrak etanol dan ekstrak etil asetat dari kulit buah manggis telah dilaporkan memliki potensi antioksidan. ${ }^{7}$ Penelitian ini bertujuan untuk mengetahui pengaruh pemberian gel ekstrak kulit buah manggis terhadap perlekatan resin komposit pada gigi pasca perawatan in-office bleaching.

\section{METODE PENELITIAN}

Penelitian ini termasuk eksperimental laboratorium dengan rancangan acak lengkap. Variabel bebas adalah konsentrasi gel ekstrak kulit buah manggis $10 \%$, 20\%, dan $40 \%$, sedangkan variabel terikat adalah nilai perlekatan resin komposit. Variabel kendali antara lain jenis resin komposit, teknik bleaching, teknik aplikasi resin komposit, waktu, dan suhu. Lama perendaman gigi dalam larutan saliva buatan dan jumlah residual hidrogen peroksida dalam gigi merupakan variabel yang tidak terkendali.

\section{Ekstraksi kulit buah manggis}

Serbuk kering kulit buah manggis diektraksi dengan metode maserasi (perendaman) menggunakan etanol 96\% (1:3) selama 5 x 24 jam. Setiap 24 jam dilakukan filtrasi dan semua filtrat digabung untuk diuapkan dengan rotary evaporator dilanjutkan dengan pemekatan menggunakan penangas air (water bath) sampai diperoleh ekstrak kental. Selanjutnya dilakukan pencucian dengan Petroleum Eter (PE) dengan ektraksi caircair (partisi) menggunakan corong pisah untuk menghilangkan senyawa pengotor seperti lemak, tanin, dan resin.

\section{Pembuatan Gel kulit buah manggis}

Ekstrak kulit buah manggis diformulasikan menjadi sediaan gel dengan konsentrasi 10\%, 20\%, dan 40\% dalam aquadest sesuai dengan formula pada Tabel 1. Demikian halnya asam askorbat yang diformulasikan menjadi gel asam askorbat 10\%. (lihat Tabel 1)

\section{Penentuan dan perlakuan terhadap sampel}

Sebanyak 25 sampel gigi dibagi menjadi 5 kelompok terdiri dari kontrol negative yaitu gigi pasca bleaching yang ditumpat resin komposit tanpa aplikasi sediaan uji, kontrol positif yang diaplikasikan asam askorbat $10 \%$, dan 3 kelompok perlakuan gel ekstrak kulit buah manggis $10 \%, 20 \%$, dan $40 \%$.

Semua sampel gigi pada permukaan labial diaplikasikan hidrogen peroksida $40 \%$ sebagai bahan bleaching sesuai dengan cara pemakaian pada kemasan. Setelah prosedur bleaching selesai, semua sampel diberikan topikal fluor kemudian dibilas dengan air. Sampel gigi selanjutnya dilakukan 
preparasi $0,5-1 \mathrm{~mm}$ pada permukaan labial yang telah dilakukan bleaching, dipastikan permukaan tersebut rata. Kelompok kontrol positif diaplikasikan asam askorbat $10 \%$ selama 10 menit selanjutnya dibilas dengan air mengalir kemudian dikeringkan. Pada kelompok perlakuan diaplikasikan gel ekstrak kulit buah manggis $10 \%, 20 \%$, dan $40 \%$ kemudian dibilas dengan air mengalir dan dikeringkan.

Selanjutnya dilakukan pemulasan etsa pada permukaan email, kemudian dibilas dan dikeringkan dengan semprotan udara. Gigi diberi bonding dan disinari dengan light cure selama 10 detik sebelum diaplikasikan resin komposit. Gigi yang telah diberi perlakuan kemudian direndam pada larutan saliva buatan selama 24 jam, kemudian dilakukan pengujian sampel.

\section{Pengujian sampel}

Pengujian yang dilakukan pada sampel menggunakan Universal Testing Machine untuk uji geser dan Scanning Electron Mircoscopy (SEM) untuk uji mikrostruktur. Sebanyak 25 sampel gigi dilakukan uji geser untuk mengetahui nilai perlekatan resin komposit, kemudian masingmasing kelompok diuji mikrostruktur.

\section{Analisis Data}

Data perlekatan resin komposit dianalisis secara statistik dengan one-way ANOVA dan dilanjutkan uji $L S D$. Data gambaran mikrostruktur gigi dianalisis secara deskriptif.

Tabel 1. Formula gel ekstrak kulit buah manggis dan gel asam askorbat

\begin{tabular}{lcccc}
\hline \multicolumn{1}{c}{ Komposisi } & $\begin{array}{c}\text { Ekstrak } \\
\mathbf{1 0 \%}\end{array}$ & $\begin{array}{c}\text { Ekstrak } \\
\mathbf{2 0 \%}\end{array}$ & $\begin{array}{c}\text { Ekstrak } \\
\mathbf{4 0 \%}\end{array}$ & $\begin{array}{c}\text { Asam } \\
\text { Askorbat10\% }\end{array}$ \\
\hline Bahan Aktif $(\mathrm{g})$ & 10 & 20 & 40 & 10 \\
Na-CMC $(\mathrm{g})$ & 1 & 1 & 1 & 1 \\
Gliserin $(\mathrm{g})$ & 2 & 2 & 2 & 2 \\
Propilen glikol $(\mathrm{g})$ & 1 & 1 & 1 & 1 \\
Propil paraben $(\mathrm{g})$ & 0,18 & 0,18 & 0,18 & 0,18 \\
Metil paraben $(\mathrm{g})$ & 0,02 & 0,02 & 0,02 & 0,02 \\
Aquadest $(\mathrm{mL})$ & 100 & 100 & 100 & 100 \\
\hline
\end{tabular}

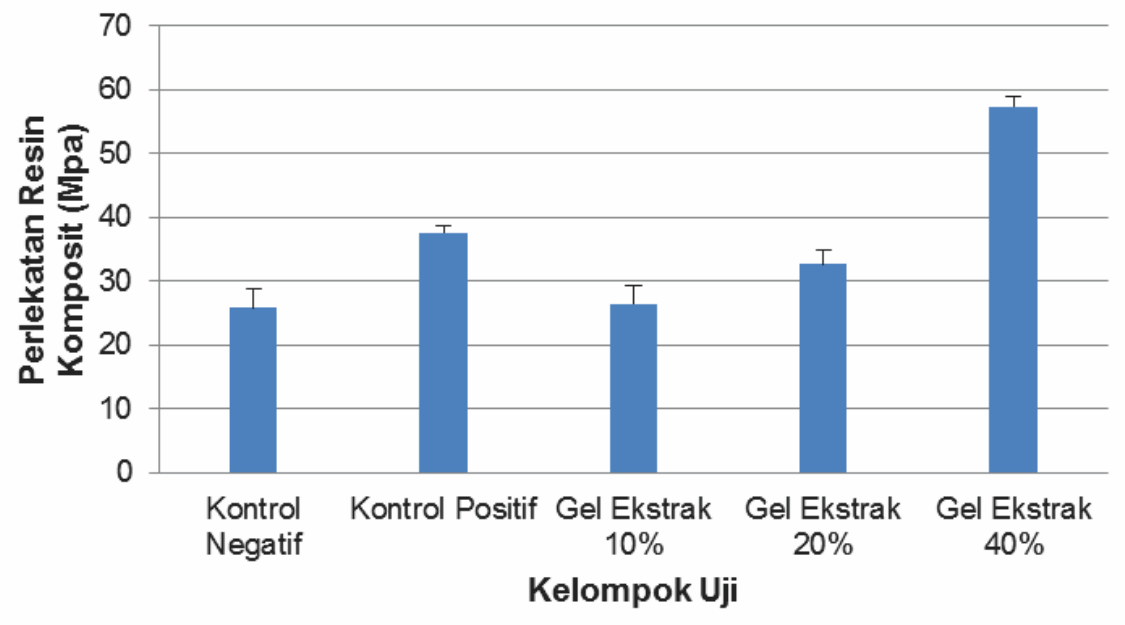

Gambar 1. Nilai Perlekatan Resin Komposit

Keterangan:

(A) Berbeda signifikan dibandingkan dengan kontol negatif $(p<0,05)$ (B) Berbeda signifikan dibandingkan dengan kontol positif $(p<0,05)$ 


\section{HASIL PENELITIAN}

\section{Perlekatan Resin Komposit}

Nilai perlekatan resin komposit diperoleh dari uji geser menggunakan Universal Testing Machine disajikan dalam bentuk diagram pada Gambar 1.

Nilai rata-rata perlekatan resin komposit pada kelompok kontrol negatif, kontrol positif, gel ekstrak kulit buah manggis $10 \%, 20 \%$, dan $40 \%$ secara berturutturut sebesar 25,82 $\pm 2,88 ; 37,68 \pm 1,06 ; 26,54 \pm 2,68$; $32,64 \pm 2,33$; dan 57,34 $\pm 1,51$ Mpa. (lihat Gambar 1)

\section{Gambaran Mikrostruktur Permukaan Email}

Uji Scanning Electron Microscope (SEM) dilakukan untuk membandingkan struktur permukaan email gigi pasca perawatan in-office bleaching antara kelompok kontrol dan kelompok perlakuan yang telah dilakukan uji geser. Hasil uji SEM dapat dilihat pada Gambar 2. Pada Gambar 2 terlihat adanya perbedaan antara kelompok kontrol negatif dan kontrol positif. Pada kontrol negatif (2A) tampak permukaan email yang kasar namun tidak terdapat fraktur email. Kontrol positif (2B) tampak permukaan email yang kasar dan terdapat gambaran fraktur pada permukaan email. Hasil gambaran mikrostruktur pada kelompok perlakuan ekstrak kulit buah manggis dapat dilihat pada Gambar 3.
Kelompok perlakuan dengan gel ekstrak kulit buah manggis $10 \%$ terdapat fraktur email yang tidak terlalu banyak dan kurang jelas, namun pada gel ekstrak $20 \%$ terlihat cukup banyak email yang mengalami fraktur. Pada gigi yang diaplikasi gel ekstrak $40 \%$ terlihat fraktur email lebih banyak dan besar ditandai dengan permukaan yang kasar serta terdapat sisa bahan adesif pada permukaan email.

\section{PEMBAHASAN}

\section{Perlekatan Resin Komposit}

Nilai perlekatan resin komposit pada aplikasi gel ekstrak kulit buah manggis semakin meningkat sebanding dengan kenaikan konsentrasi gel. Namun demikian, nilai perlekatan resin pada gel ekstrak $10 \%$ tidak berbeda signifikan dibandingkan dengan kontrol negatif. Perlakuan gel ekstrak kulit buah manggis $10 \%, 20 \%$, dan $40 \%$ secara statistik berbeda signifikan dibandingkan aplikasi asam askorbat $10 \%$. Gel esktrak kulit buah manggis $40 \%$ menunjukkan hasil terbaik dalam mengeleminasi residual hidrogen peroksida pada gigi pasca perawatan in-office bleaching. Dengan demikian, gel ekstrak kulit buah manggis $40 \%$ memiliki aktivitas antioksidan yang lebih tinggi dibandingkan

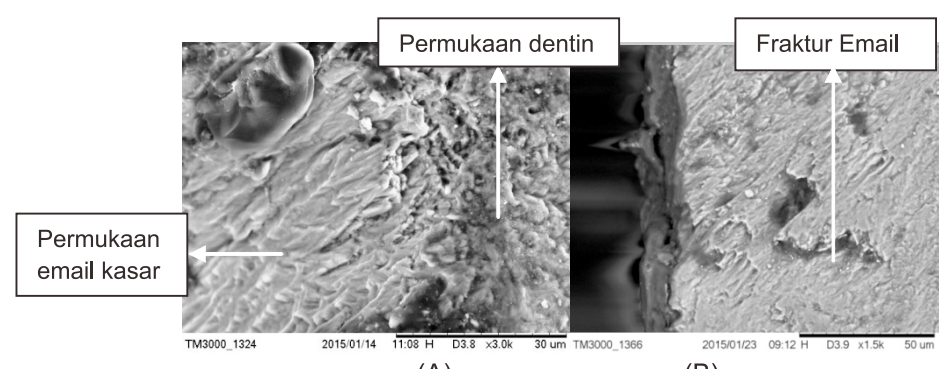

(A)

(B)

Gambar 2. (A) Permukaan gigi kelompok kontrol negatif terlihat permukaan email yang kasar namun tidak terdapat fraktur email; (B) Permukaan gigi kelompok kontrol positif terlihat gambaran fraktur pada permukaan email

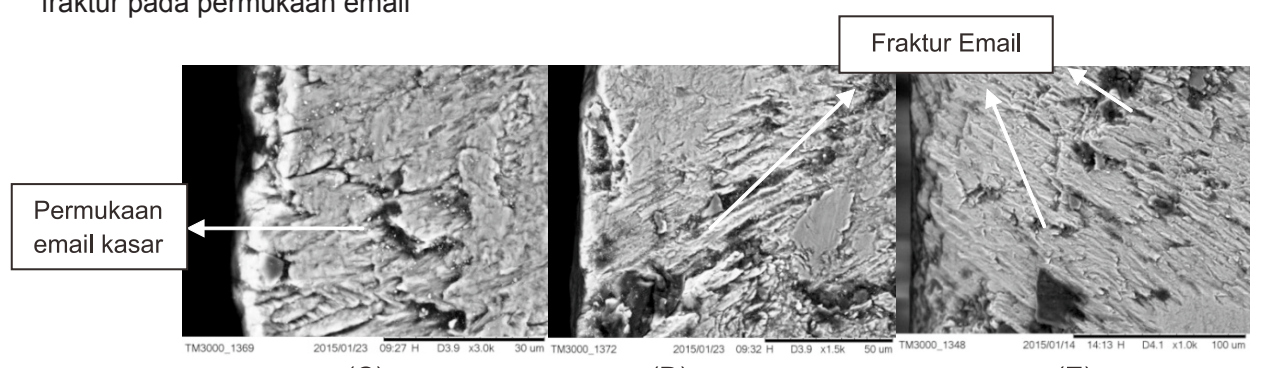

(C)

(D)

(E)

Gambar 3. C) Permukaan gigi pada perlakuan gel ekstrak kulit manggis $10 \%$ terdapat fraktur email yang tidak banyak dan kurang jelas; D) perlakuan gel ekstrak kulit manggis $20 \%$ terlihat fraktur email yang cukup banyak; E) perlakuan gel ekstrak kulit manggis $40 \%$ terlihat fraktur email lebih banyak dan besar dibandingkan kelompok perlakuan lain. 
asam askorbat $10 \%$ dan gel ekstrak kulit buah manggis $20 \%$. Semakin tinggi konsentrasi ekstrak maka semakin meningkat aktivitas antioksidannya. ${ }^{9}$

Sifat antioksidan pada ekstrak kulit buah manggis memiliki nilai $\mathrm{EC}_{50} 8,5539 \mu \mathrm{g} / \mathrm{ml}$, sedangkan vitamin $\mathrm{C}$ memiliki nilai $\mathrm{EC}_{50} 3,3676 \mu \mathrm{g} / \mathrm{ml}$. Hal ini menunjukkan bahwa vitamin $\mathrm{C}$ dengan perlakuan dan konsentrasi yang sama dengan ekstrak kulit buah manggis memiliki potensi antioksidan lebih baik dibandingkan dengan ekstrak kulit buah manggis. ${ }^{8}$ Hasil penelitian ini menunjukkan bahwa gel kulit buah manggis $20 \%$, dan $40 \%$, dan asam askorbat $10 \%$ dapat mengeleminasi residual hidrogen peroksida pada gigi pasca perawatan in-office bleaching. Agen antioksidan dapat menghasilkan reaksi redoks yang mengubah suatu ikatan substrat teroksidasi sehingga akan menghilangkan radikal bebas yang terdapat pada gigi pasca perawatan inoffice bleaching, dan secara tidak langsung dapat memperbaiki polimerisasi resin bonding pada gigi pasca in-office bleaching. ${ }^{4}$

Eliminasi residual hidrogen peroksida pada gigi pasca perawatan in-office bleaching akan berpengaruh terhadap proses polimerisasi bahan adesif dan resin komposit. Bahan adesif dapat terpolimerisasi dengan baik dan resin komposit mampu berpenetrasi masuk ke dalam tubuli dentin dan celah pada email lebih dalam, sehingga dapat meningkatkan ikatan antara gigi dan bahan adesif yang mengakibatkan perlekatannya semakin kuat. Hal ini sejalan dengan penelitian sebelumnya yang melaporkan bahwa agen antioksidan yang digunakan pada gigi pasca perawatan in-office bleaching dapat meminimalkan terjadinya bubblelikestructure dalam lapisan bahan adesif yang terpolimerisasi yang mengakibatkan penurunan kekuatan perlekatan resin komposit pada gigi pasca perawatan in-office bleaching. ${ }^{4}$

\section{Gambaran Mikrostruktur Permukaan Email}

Uji SEM dilakukan untuk melihat perbedaan mikro struktur permukaan email gigi pada kelompok kontrol dan kelompok perlakuan. Gambar 2 dan 3 menunjukkan adanya permukaan email yang kasar, hal itu disebabkan karena email gigi memiliki sifat premeabelitas yang tinggi terhadap hidrogen peroksida. ${ }^{10}$ Kemampuan penetrasi dari hidrogen peroksida sebagai bahan bleaching kedalam email, dapat merusak kandungan anorganik sampai permukaan email yang paling dalam. ${ }^{4,10}$ Kandungan kalsium pada email gigi akan berkurang selama proses perawatan bleaching. Kemampuan hidrogen peroksida membentuk radikal bebas yang berinteraksi dengan molekul organik yang menyerap warna dan mengoksidasi makro molekul, pigment stain, memecah pewarnaan pada gigi menjadi molekul yang lebih kecil dengan warna yang lebih terang. ${ }^{11}$ Proses mekanisme bleaching tersebut dapat menimbulkan terjadinya porositas pada email sehingga permukaan email menjadi kasar. $^{4}$

Gambar 2 menunjukkan bahwa terdapat perbedaan mikrostruktur email pada kelompok kontrol negatif dan kelompok kontrol positif yang diaplikasikan asam askorbat $10 \%$. Pada kontrol negatif tampak permukaan email mengalami fraktur akibat lepasnya perlekatan antara resin bonding dengan email gigi. Fraktur yang dimaksud adalah patahan yang terjadi antara email dengan resin bonding ataupun antara resin bonding dengan komposit itu sendiri akibat dari uji geser. Pada pemberian asam askorbat $10 \%$ tampak permukaan email yang kasar akibat dari bahan bleaching dan terlihat adanya gambaran resin bonding pada permukaan email. Perlekatan resin bonding dengan email gigi yang semakin kuat menyebabkan perlekatan adhesif yang semakin kuat. ${ }^{4}$ Resin bonding yang tertinggal pada permukaan email akan mengalami fraktur akibat uji geser.

Resin bonding yang mengalami fraktur pada permukaan email juga dapat dilihat pada kelompok perlakuan gel ekstrak kulit buah manggis $10 \%, 20 \%$, dan 40\% (Gambar 3). Permukaan resin bonding yang mengalami fraktur pada permukaan email terlihat lebih banyak pada perlakuan gel ekstrak kulit buah manggis $20 \%$ dan $40 \%$, dibandingkan dengan perlakuan gel ekstrak kulit buah manggis $10 \%$. 


\section{KESIMPULAN}

Gel ekstrak kulit buah manggis 20\% dan $40 \%$ dapat memperbaiki perlekatan komposit dan berpotensi sebagai antioksidan alami pada gigi pasca in-office bleaching.

\section{DAFTAR PUSTAKA}

1. Tarigan R. Perawatan Pulpa Gigi (Endodonti). Ed. 2. Jakarta: EGC; 2006. h.208-217

2. Boksman L. Current Status of Tooth Whitening: Literature Review. Dentistry Today. 2006; 25 (9):76-79.

3. Sundoro EH, Dewi AMR, Kamizar. Pengaruh Pemakaian Bahan Pemutih Gigi yang Mengandung $\mathrm{H}_{2} \mathrm{O}_{2} 6 \%$ Terhadap Email. Jurnal Konservasi. 2000; 7(1): 1-6.

4. BorgesAB, Koga AF, Torres CRG. The Effect of Anti-oxidant Agents as Neutralizers of Bleaching Agents on Enamel Bond Strength. Braz J Oral Sci. 2006; 5(16): 971-976.

5. Danesh-Sani SA, Esmaili M. Effect of $10 \%$ Sodium Ascorbat Hydrogel and Delayed Bonding on Shear Bond Strength of Composite Resin and Resin-Modified Glass lonomer to Bleached Enamel. J Conserv Dent.2011; 14(3): 241-246.

6. Jung $H A$, Su BN, Keller WJ, Mehta RG, Kinghorn AD. Antioxidant Xanthones from the Pericarp of Garcinia mangostana (Mangosteen). J Agric Food Chem. 2006; 54 (6): 2077-2082.

7. Weecharangsan $W$, Opanasopit P, Sukma M, Ngauhirunpat T, Sotanaphun U, Siripong P. Antioxidative and Neuroprotective Activities of Extracts from the Fruit Hull of Mangosteen (Garcinia mangostana Linn). Med Princ Pract. 2006; 15(4): 281-287.

8. Supiyanti W, Wulansari ED, Kusmita L. Uji Aktivitas Antioksidan dan Penentuan Kandungan Antosianin Total Kulit Buah Manggis (Garcinia mangostana). Majalah Obat Tradisional. 2010; 15(2): 64-70.

9. Sihombing CN, Wathoni N, Rusdiana T. Formulasi Gel Antioksidan Ekstrak Buah Buncis (Phaseolus vulgaris L.) dengan Menggunakan Basis Aqupec 505 HV. Fakultas Farmasi Universitas Padjadjaran. Sumedang. 2010. H.1-14.

10. Markovic M, Sieck BA, Takagi S, Chow LC, Majeti S. Diffusion of Hydrogen Peroxide ThroughSound Enamel. J Dent Res. 2000; 79: 305.

11. Gokduman K. Effect of Hydrogen Peroxide Bleaching on Human Dentin And Enamel Microstructure And Function. Thesis. Middle East Technical University. Ankara. 2005. H.160 